\title{
10. Approaches to minimum-income protection in old age: comparing the three Scandinavian countries
}

\author{
Axel West Pedersen
}

\section{INTRODUCTION}

The provision of relatively generous minimum benefits in old age has traditionally been an important distinctive feature of the Nordic pension systems and, arguably, one of the hallmarks of the ideal type notion of the Nordic welfare state. This chapter offers a comparative study of the current minimum-income protection schemes for old-age pensioners in Denmark, Norway and Sweden.

The primary purpose of the chapter is to describe and assess developments in the overall generosity of minimum protection provided through the pension system proper and other relevant instruments. To what extent has the historical legacy of generous minimum protection been upheld in the three countries, despite extensive reforms intended to improve the financial sustainability of the respective systems?

Second, the interaction between minimum protection and the earnings-related components of the respective pension systems will be analysed with a view to the implications it might have for distributive outcomes and labour market incentives. Additional aspects covered in the comparison are the implicit equivalence scales, residency requirements and flexibility offered with respect to the timing of benefit take-up.

It is a central premise of the chapter that the overall distributive outcome among old-age pensioners in each country is strongly dependent on the generosity of minimum protection schemes and the way they are designed to interact with the contributory, earnings-related parts of the respective national systems. Deciding on the level of minimum protection, and on the way minimum benefits are integrated with the earnings-related parts of the system, poses intricate dilemmas for policy makers that over the last decades have been met with rather different responses in the three Scandinavian countries. 
After providing a brief sketch of the historical background in Section 2, the current architecture of minimum protection is described in Section 3. Section 4 presents findings on the development over time in the generosity of minimum protection, while Section 5 investigates the interaction between minimum protection and contributory (public and private) pensions. The findings are summarised and discussed in the concluding section.

\section{A SKETCH OF THE HISTORICAL BACKGROUND}

The pension systems in the three Scandinavian countries are rooted in what we might call a Nordic/Anglo-Saxon tradition for redistributive minimum protection in old age. This tradition is characterised by providing flat-rate (universal or means-tested) benefits to all elderly people based on citizenship or residence. The approach that is sometimes somewhat ahistorically referred to as 'Beveridgean' can be contrasted with the 'Bismarckian' social insurance tradition, with its emphasis on prior contributions and earnings-related benefits, that has tended to dominate in Continental Europe.

Denmark pioneered the development of this minimum protection approach in 1891 by introducing a law that required municipalities to provide cash benefits to the elderly without alternative means of subsistence. However, this first Danish pension law was little more than a system of poor relief targeted towards the elderly. Therefore, it can be argued that a distinctive Scandinavian approach to pension provision was only fully developed during the 1930s, when Denmark, Sweden and Norway introduced reforms that led to significantly improved levels of minimum-income protection for all elderly residents in the form of (mainly) tax-financed, flat-rate benefits (Hort 1990; Pedersen and Kuhnle 2017; cf. Baldwin 1990). While old-age benefits from these reformed systems were subject to both income and asset testing, little administrative discretion was involved, and the tapering rules were relatively mild. As a consequence, these old-age benefits were firmly rights-based and only a minority of the elderly population was excluded from receiving benefits (see Pettersen 1982; Hort 1990; Petersen and Petersen 2009). Also in Finland, where the pension system had previously followed the insurance path, a tax-financed minimum benefit for the elderly was introduced in the late 1930s (Salminen 1993).

In the early post-war period, a common reform trend in the three Scandinavian countries was to abandon or limit the use of means-testing and introduce full universalism in the provision of old-age benefits. In Sweden (1946) and Norway (1959), means-testing of old-age benefits was completely abolished, and minimum protection began to take the form of a truly universal, flat-rate income transfer to all residents above a specific age (67 in Sweden and 70 in 
Norway) (Elmér 1986; Pettersen 1987). Also, in Denmark universal old-age benefits were introduced through legislation enacted in the 1950s, but here the introduction and expansion of a basic universal benefit was combined with the preservation of an income- and asset-tested supplementary benefit (Petersen and Petersen 2009).

These moves towards more universalistic systems of minimum protection were quickly followed (or even partly preceded) by debates on the possible introduction of a more insurance-like second tier of earnings-related pensions. In Sweden (1961) and Norway (1967) this debate resulted in major reforms of the respective public pension systems, introducing a second tier of earnings-related benefits on top of the existing first tier of flat-rate benefits (Molin 1965; Pedersen 1990). The national pension systems of these two countries have since been characterised by a compromise between a residency-based minimum protection of the first tier and a contributory insurance logic of the second tier. Both the Swedish 'ATP' system (Allmän tilläggspension) and the somewhat more modest Norwegian Folketrygdens tilleggspensjon were 'point systems' where benefits were linked to the earnings levels enjoyed over a number of the best years ( 15 and 20 years respectively) and requiring a longer contribution period (30 and 40 years, respectively) to receive full benefits.

In Denmark, however, a general, obligatory second tier of earnings-related pensions was never introduced. A rather modest obligatory contributory pension scheme (ATP; Arbejdsmarkedets Tillcegspension) was introduced in the 1960s, but benefits and contributions in this scheme were tied to years of employment and not the level of earnings. Several attempts were made in both the 1970s and late 1980s to introduce a more substantive, earnings-related second tier, but they all failed (Vesterø Jensen 1985). Thus, the Danish public pension system has remained faithful to the goal of providing flat-rate (partly means-tested) benefits only. Instead, a comprehensive system of negotiated defined-contribution occupational pension schemes was developed in the 1990s. These industry-wide schemes automatically enrol all workers covered by the relevant collective wage agreement, and they encompass more than 80 per cent of the Danish workforce (Kangas, Lundberg and Ploug 2010).

In the 1970s and 1980s, the structure of minimum protection was gradually changed in both Sweden and Norway. In the early 1970s, a targeted supplementary benefit was introduced to top up the universal basic pensions in both countries. The supplementary benefits were only tested against benefits from the earnings-related second tier, but with a 100 per cent taper. In this way they functioned as a sort of guaranteed-minimum-earnings-related benefit. Over time these supplementary benefits were systematically increased in order to compensate for the fact that the level of universal basic pensions was lacking behind developments in average wages. However, an unintended side effect of the expansion of the targeted supplements was that individuals with relatively 
low lifetime earnings (like women working part-time for significant parts of their life course) would not in reality benefit from having contributed to the earnings-related part of the system.

In the 1990s, Sweden once again pioneered a radical reform path by replacing the existing defined-benefit system with a notional defined contribution (NDC) system and a smaller, fully funded (FDC) system in which the accumulation of pension rights is proportional to earnings up to an annual ceiling just around a full-time average wage (7.5 times the 'income base amount') and featuring both automatic longevity adjustments of benefits and a flexible, actuarially neutral system for claiming benefits (Könberg et al. 2000). At the same time, the provision of a universal benefit floor was abandoned in favour of a targeted minimum benefit (guarantee pension) that is tested (tapered off) against benefits from the NDC and FDC systems.

About ten years later, Norway followed suit by introducing an NDC reform that started to take effect from 2011 (Christensen et al. 2012). Just like the Swedish prototype, the Norwegian reform introduced automatic longevity adjustments of benefits and a flexible, actuarially neutral system for claiming benefits, and it also involved the abandonment of a universal benefit floor in favour of a targeted minimum pension ('guarantee pension') that is tapered off against benefits from the NDC system.

\section{THE CURRENT CONTEXT AND ARCHITECTURE OF MINIMUM PROTECTION}

While Denmark has developed a private, negotiated system of earnings-related pension schemes, Sweden and Norway both feature an obligatory public scheme with contributory, earnings-related benefits. Despite these differences in the institutional set-up, all three systems can be seen as having an earnings-related core aimed at providing (contributory) benefits that are roughly proportional to lifetime earnings.

In the Danish negotiated schemes, contribution rates range from 12 to 18 per cent of annual earnings, where one-third is typically paid by the employee and two-thirds by the employer (Pedersen et al. 2018). In Sweden contributions to the NDC system are fixed at 16 per cent of annual earnings, but on top of that a small, fully funded FDC system (premiepension) takes the combined contribution rate up to 18.5 per cent of annual earnings below the ceiling. The Norwegian NDC system is financed out of general taxation. The accrual rate is fixed at 18.1 per cent of annual earnings up to a ceiling of $720,000 \mathrm{NOK}$ in 2020, corresponding to approximately 120 per cent of an average full-time wage.

The proportionality between lifetime earnings and retirement benefits comes with important modifications in all three countries. The Norwegian and 
Swedish NDC systems contain (or are flanked with) a number of redistributive features, like a ceiling on annual earnings that count for the accrual of pension rights, subsidised accrual for parents with low earnings due to caring for small children, and accrual based on the receipt of social security benefits. These modifications are generally missing in the private, decentralised Danish system. In addition, the Norwegian and Swedish NDC systems are free from the inegalitarian implications of the exposure to capital market risks that are present in the fully funded Danish schemes, and differences in longevity between men and women, and between occupational groups, do not enter the annuity conversion upon retirement. Annuity conversion is required to be sex-neutral within each of the Danish negotiated schemes, but differences in the gender composition of the risk pools of the respective schemes are not compensated for (see Pedersen et al. 2018).

On the other hand, the Danish ATP system, with its flat-rate accrual formula, is a potentially equalising component that has no equivalent in the two other Scandinavian countries. The lack of risk pooling between different labour market segments in the Danish FDC schemes will also, to some extent, have egalitarian implications since groups of workers with relatively low education/ earnings and low life-expectancy are not required to enter a common risk pool with high-education/earning groups and high life-expectancy. Finally, both Sweden and Norway have developed occupational pension schemes on top of the earnings-related public schemes with benefit profiles that tend to be more or less regressive in contrast to the largely proportional Danish occupational pension schemes. The regressive nature of the schemes is primarily related to the fact that contribution rates are higher for earnings above the ceiling in the public NDC systems.

Hence, in terms of their implications for the distribution of income among old-age pensioners, the pay-as-you-go financed NDC systems of Sweden and Norway, and the fully funded Danish defined-contribution schemes, cannot be expected to be strongly divergent. None of them will in and by themselves rule out the risk of income poverty in old age, and none of them are explicitly designed to achieve significant and systematic income redistribution towards people with low lifetime earnings. These tasks are left to be handled by the respective minimum protection schemes.

\section{The Nature of Minimum Pensions}

All rich countries offer some kind of minimum-income guarantee for old-age pensioners - either through the pension system proper or in the form of social assistance (see OECD 2019, pp. 134-136). The minimum pension can be either universal or targeted or a combination, and targeting can be narrowly related to public pension income, or broader, including other income compo- 
nents like private pensions and income from capital, and possibly also involve an assets test.

While the three Scandinavian countries for several decades provided universal flat-rate benefits as an important part of the minimum protection system, this is no longer the case in the reformed Swedish and Norwegian systems. Only in Denmark does a universal basic benefit (Folkepensionens grundbeløb) continue to be the backbone of the minimum protection offered to old-age pensioners. The Danish basic benefit is in fact subject to a (relatively mild) earnings test, but it is not tested against other pension income nor against income from capital. Since a possibility has been introduced to voluntarily postpone the take-up of the basic benefit on actuarially neutral terms, the significance of the earnings test has been further reduced and the universalistic nature of the benefit has been strengthened. As already mentioned, a means-tested supplementary benefit (Pensionstilloeg) has always been part of the minimum pension in Denmark, but its role was increased in the mid-1990s when the supplement was raised to constitute roughly half of the total minimum pension for a single pensioner. Until 2018 the minimum pension (grundbeløb and pensionstillagg) could be claimed at age 65 , but beginning in 2019, and over the next three years, the pensionable age is to be raised by half-a-year per calendar year to reach 67 by 2022. The indexation of minimum pensions in Denmark is linked to the development in gross wages. For many years, a deduction of 0.3 percentage points was made from the wage indexation (but only in years when wages rose by at least 2.3 per cent), but this practice was abandoned in 2018 , introducing full wage indexation of the minimum pension taking effect from 2019.

In both Sweden and Norway, the introduction of a guarantee pension to replace the former dual minimum protection schemes was associated with an explicit intention to uphold the same level of minimum protection as under the old system.

In Sweden, the design of the minimum pension guarantee was discussed in relation to three basic concerns: (a) not seriously reduce compensation levels for lower earnings levels compared to the existing system, (b) guarantee that all pensioners would have at least some effect of accrued NDC pension rights and (c) limit the share of the population whose marginal pension accrual was affected by the withdrawal of the benefit guarantee (SOU 1994, p. 214). While the first and second of these concerns require that the rate of withdrawal should be mild and always lower than 100 per cent, the third calls for a steep and rapid withdrawal. In the legislation adopted in 1998 it was decided to combine an initial 100 per cent withdrawal with a taper of 48 per cent for earnings-related benefits in excess of a certain threshold. This solution ensures that all except a small minority in the very lowest part of the earnings distribution will have at least some effect of contributions paid into the NDC and FDC schemes, and 
it ensures that the combined benefit profile is progressive over a larger part of earnings distribution. However, the downside is that a substantial share of the Swedish population - given the present ratio between average earnings and the minimum guarantee - can expect to be affected by the 48 per cent taper and, hence, have their effective marginal pension accrual seriously curtailed (Scherman 2001). Although the Swedish reformers in this way made significant concessions to distributive concerns in the short run, they gave priority to the principle of proportionality between contributions and benefits and, hence, to strengthening labour market incentives in the longer run. While all parameters and pension rights accrued in the NDC scheme are to be indexed with the development in average wages, the guarantee pension is indexed with prices only. In this way the minimum benefit guarantee is programmed to be gradually marginalised in line with the growth in real wages.

The Swedish guarantee pension can be claimed from age 65. It offers no possibility to postpone the take-up with actuarial adjustments, but there is no earnings test affecting the right to claim benefits and the size of benefits received.

In Norway, policy makers chose a somewhat different approach. In the detailed reform proposal prepared by the Stoltenberg government in 2006, it was suggested a constant taper of 80 per cent be applied against earned (contributory) pension rights. In this way all wage earners will always be guaranteed an increment in pension income from even the smallest lifetime earnings/contributions. However, as long as you remain within the taper interval, the marginal gain will be relatively modest (20 per cent; see Pedersen 2010), and the taper interval effects a large part of the distribution of lifetime earnings. The Norwegian policy makers chose indexation rules that link the minimum pension to developments in average wages, but with a deduction for increases in longevity among successive birth cohorts similar to the longevity adjustment integrated in the annuity divisor for the NDC benefits. In this way the benefit structure (the balance between minimum benefits and NDC benefits) should remain constant in the long run while benefit levels were set to decline in relative terms in line with future increases in longevity. In Norway the normal age of withdrawing the guarantee pension is set at age 67 (similar to the normal retirement age in the old system), but in contrast to the Swedish system an opportunity is offered to start claiming benefits earlier and postpone the claiming of guarantee benefits with full actuarial adjustments. However, early benefit claiming is strongly limited by a rule saying the resulting total annual pension benefit (the sum of NDC and guarantee benefits) should at least be at the minimum pension level at age 67 (Pedersen 2018). 


\section{Taxation, Housing Benefits and Schemes for Individuals with Short Residence}

In Denmark, since the mid-1990s the taxation of old-age pensioners and of the minimum retirement benefits has been completely normalised, with the consequence that the recipients of minimum benefits pay a significant share of gross benefits in taxes. The income taxation of old-age pensioners and pension income in Sweden has also been largely normalised. In fact, after the introduction of an in-work tax credit (the so-called jobbskatteavdraget) in the 2000s, the taxation of a certain income from work has in periods been milder than the taxation of a similar income from pensions, but in recent years new special tax reliefs have been granted to old-age pensioners. By contrast, Norway has maintained favourable tax rules for pensioners with a view to making sure that pensioners who depend on minimum pensions only will not pay any income tax. After the pension reform of 2011 this was achieved primarily through a special targeted tax credit to old-age pensioners with low pension incomes (Pedersen 2010).

In all three countries old-age pensioners can apply for housing allowances on different (more generous) terms than the general population, and the provision of housing benefits can be seen to add to the minimum protection offered to old-age pensioners. As we shall see, the significance of housing allowances for minimum protection in old age is currently largest in Sweden, followed by Denmark and Norway. In all three countries the housing allowances are subject to means-testing (testing against income and wealth of the household) and depend on the size of housing expenditure. In Denmark a number of supplementary means-tested benefits should also be counted in as part of the minimum protection offered to old-age pensioners, including, for example, a special means-tested supplement (Aldrecheck), and a supplement to help cover expenditures on heating (Varmetilloeg) (see Forsikring og Pension 2019).

In all the Scandinavian countries a residency test is applied to the receipt of minimum pensions. To receive full minimum benefits, 40 years of residency as an adult (four-fifths of the adult life phase) before reaching the pensionable age is required, and minimum benefits are reduced proportionally in cases where the residency period is shorter than this. In Denmark it was decided in 2018 to sharpen this criterion. Beginning in 2026 a person will be required to have been a resident for nine-tenths of the period between age 15 and the pensionable age in order to receive the full minimum pension, and the minimum pension is reduced proportionally if the share of life between age 15 and the pensionable age spent abroad exceeds one-tenth (Forsikring and Pension 2019, p. 163).

However, in the 2000s in Sweden and Norway it was decided to introduce subsidiary minimum schemes to cater to immigrants and others with a shorter 
residency record before reaching the pensionable age. In Sweden the subsidiary scheme (Äldreförsörjningsstöd) was introduced in 2003 while a similar scheme (Supplerende stønad) intended for elderly people who failed to meet the residency requirement to receive a full minimum pension was put in force in Norway in 2005. In the Norwegian version, benefit levels are identical to the levels provided through the normal minimum pension benefits. The only difference is that benefits from this residual scheme are strictly means-tested with a 100 per cent taper against all other incomes of the individual or the household, and benefits cannot be exported to other countries. The latter also applies to the Swedish equivalent, but here benefit levels are significantly lower than the guarantee pension offered to old-age pensioners with a full residency record.

\section{THE GENEROSITY OF MINIMUM PROTECTION}

Figure 10.1 depicts the development in the level of minimum pensions (for single pensioners) net of taxes provided in the three countries between 1998 and 2019.

The top panel presents the development in the real value of minimum benefits measured in national currencies (2019 price levels). It shows how the real value of minimum pensions over the observation period has grown very fast in Norway, while it has been more stable in the two other countries. Over this period the real value of the minimum pension for a single pensioner in Norway has increased from NOK 10,500 per month to NOK 16,900 per month adjusted to 2019 prices, corresponding to an accumulated real increase of 61 per cent. In addition to full wage indexation that has prevailed until the onset of the Norwegian pension reform, the level of the minimum pension was raised by discrete political decisions on a number of occasions. However, the latest increases only apply to the minimum benefits offered under the old system that is still in the process of being phased out, and, therefore, the development of the minimum pensions can be expected to become less spectacular in the coming years as the longevity adjustment factor will start to take its toll. In Denmark the real value of the net minimum pension has increased from DKR (2019) 8,100 to DKR 10,700. Also, in Sweden the real value of the net minimum pension has increased from SEK 5,900 to SEK 7,900 adjusted to 2019 price levels. The real increase in the Swedish minimum pension is somewhat surprising, given the strict adherence to price indexation of the guarantee pension. However, part of the increase appears to be related to the transition to the guarantee pension and the parallel phasing out of the dual minimum benefit from the pre-reform pension system. In addition, reliefs in the taxation of old-age pensioners, and a discrete increase in the level of the guarantee pension taking effect in 2019, have contributed as well. 
Real value in national currency (kroner), 2019

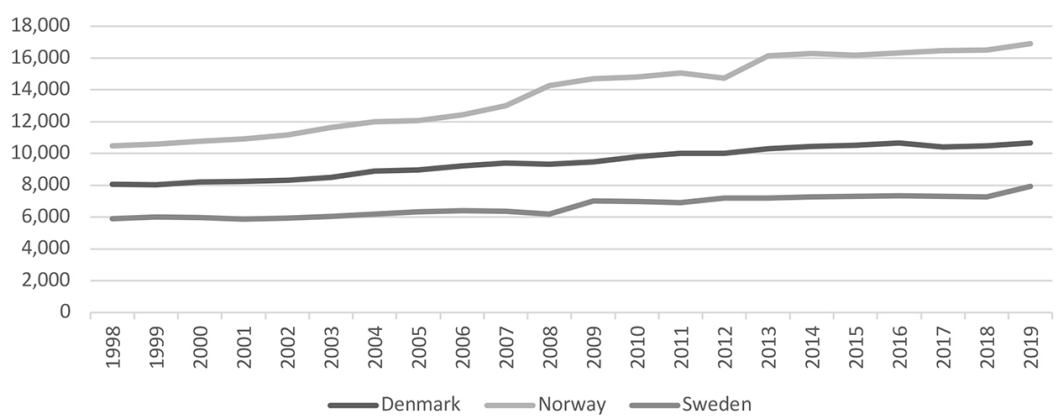

Real value in PPS US\$, 2019

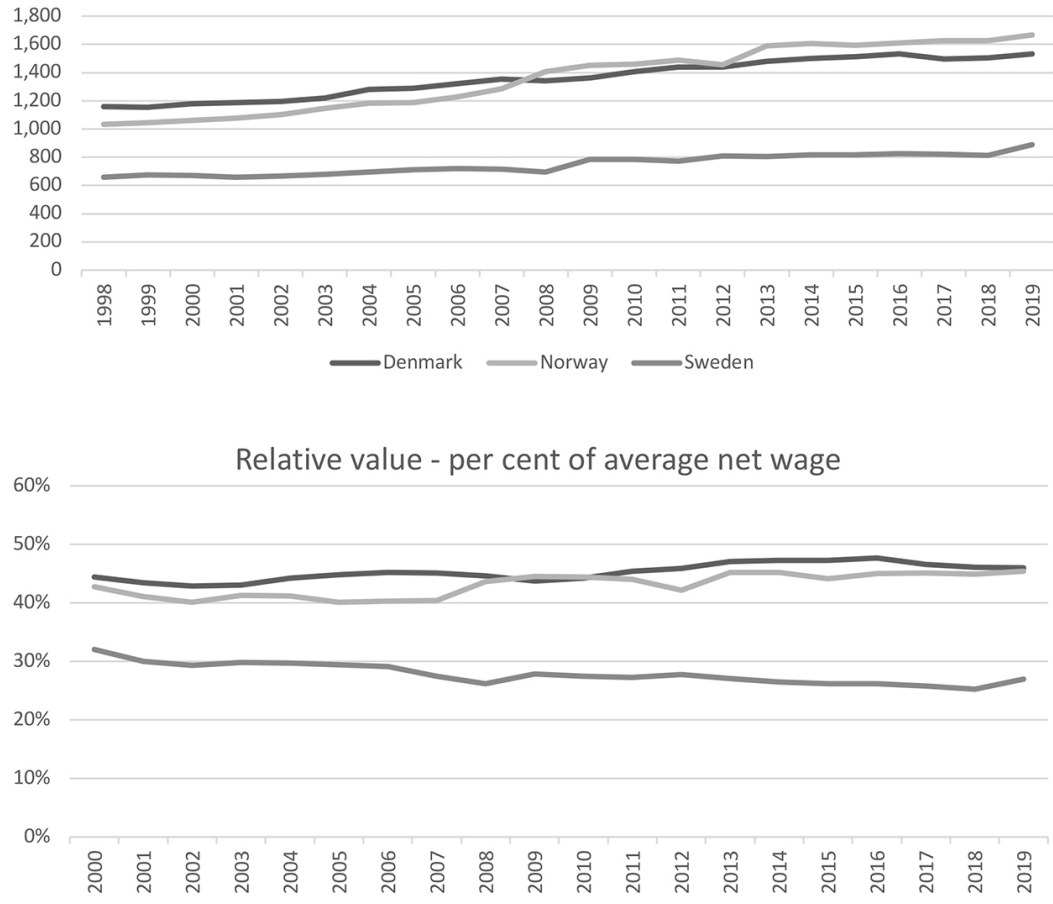

Source: NOSOSCO annual reports 1998 to 2016/2017, supplemented with author's calculations.

Figure 10.1 Minimum pension net of tax for a single pensioner per month, 1998-2019 
In the middle panel, the real purchasing powers of the monthly net minimum pensions are made comparable across countries by converting them to purchasing power parities (PPS; US\$) using 2019 conversion rates. Adjusting for cross-national differences in price levels shows that the purchasing power of the net minimum pension offered to single pensioners is roughly equivalent in Denmark and Norway, albeit with a slightly more positive development over time in Norway. Sweden, by contrast, lags seriously behind the two Scandinavian neighbours. In 2019 the purchasing power of the Norwegian net minimum pension is almost double the level found in Sweden, and the level in Denmark is only marginally behind. But these results must be seen in light of the significant differences in the general level of prosperity among the three countries, with Norway being by far the richest country.

Finally, therefore, the bottom panel of Figure 10.1 presents the development in minimum benefit levels measured relative to the national average wage net of taxes. ${ }^{1}$ It shows that while the net relative generosity of minimum pensions has remained stable at a level around 45 per cent in both Denmark and Norway, the benefit level is much lower in relative terms in Sweden and shows a declining trend over time from about 32 per cent in the year 2000 to 25 per cent in 2018 and 27 per cent in 2019.

\section{Implicit Equivalence Scales}

An important caveat to the preceding comparison of the level of minimum pensions is that it has focused on single pensioners only. The finding that Denmark performs almost on a par with Norway both in terms of the purchasing power of minimum pensions and in terms of relative generosity (anchored in the net average wage) does not hold up for old-age pensioners living in couples.

As shown in Table 10.1, in both Norway and Sweden the minimum benefit offered to old-age pensioners living in couples is almost at the same level as the benefit offered to pensioners living alone. In Denmark, by contrast, the minimum pension for a single pensioner is significantly higher, presumably with a view to compensating for the lack of economies of scale and the higher living costs facing single-member households.

In inequality and poverty measurement, household incomes are routinely adjusted with equivalence scales that are supposed to reflect differences in economic needs between different household types. The widely used European Union (EU) equivalence scale assumes that a household with two adults (a pensioner couple) needs 1.5 times more income than a single-member household (a single pensioner) to achieve the same level of economic wellbeing. It is possible to extend this concept to compare the implicit equivalence scales embedded in the minimum pension system, by calculating the ratio between benefits offered to single and married/cohabitating pensioners. 
Table 10.1 Minimum pension benefit per month for single pensioners and pensioners living in a couple; national currencies (Kroner) 2019

\begin{tabular}{l|l|l|l}
\hline & \multicolumn{2}{l}{$\begin{array}{l}\text { Married/cohabitating } \\
\text { pensioner }\end{array}$} & \multicolumn{2}{l}{$\begin{array}{l}\text { Single pensioner } \\
\text { scale }\end{array}$} \\
\hline Denmark & 11,247 & 14,717 & 1.31 \\
\hline Norway & 15,159 & 16,902 & 1.11 \\
\hline Sweden & 7,363 & 8,254 & 1.12 \\
\hline
\end{tabular}

Sources: Forsikring and Pension 2019, www.nav.no/no/nav-og-samfunn/kontakt-nav/oversikt -over-satser/minste-pensjonsniva, www.pensionsmyndigheten.se/forsta-din-pension/sa-fungerar -pensionen/garantipension-om-du-har-lag-pension

The last column of Table 10.1 shows the implicit equivalence scale of minimum pensions in the three countries. While the implicit equivalence weight of the Danish minimum pension is 1.31 , it is much lower in Norway and Sweden, at 1.11 and 1.12 respectively. Undoubtedly the implicit equivalence scales are more single-pensioner-friendly when housing benefits are taken into account.

In Norway the minimum pension system used to differentiate more strongly between single and married/cohabitating pensioners, but over the last decade the political emphasis has been on moving towards a more individualised benefit structure where the household situation is not taken into account (Pedersen 2018). In Sweden, by contrast, a recent white paper argues in favour of increasing the implicit equivalence scale of the minimum pension (Socialdepartementet 2018).

\section{The Generosity of the Total Package of Minimum Protection}

The three Scandinavian countries all operate housing allowance schemes with special provisions for old-age pensioners, and these schemes therefore should arguably be counted in as part of the minimum-income protection offered to old-age pensioners. The role of housing allowances is relatively modest in Norway and more important in both Denmark and (particularly) in Sweden. Therefore, the inclusion of housing allowances into the assessment of the generosity of minimum protection is likely to modify the picture of cross-national differences.

Figure 10.2 shows how pension benefits proper, housing allowances ${ }^{2}$ and finally the payment of income taxes affect the level of minimum protection among old-age pensioners offered in the three countries in 2019. As in Figure 10.1, each panel in Figure 10.2 applies a different metric for the measurement of benefit levels: national currency, PPS US\$ and finally a relative measure in terms of the respective average wage net of taxes. 


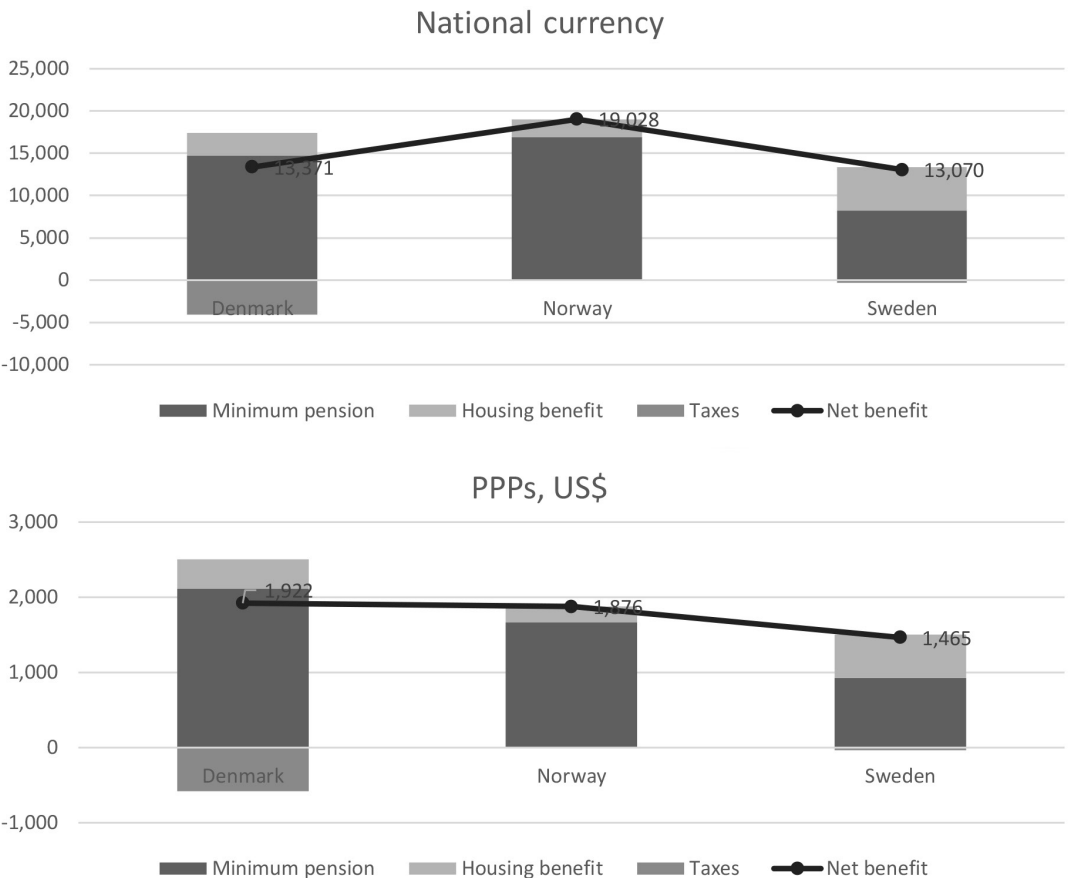

Per cent of net average wage

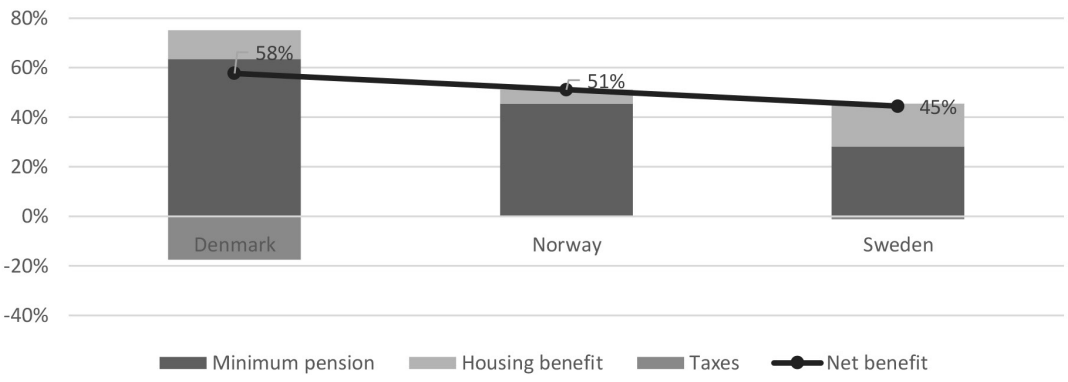

Sources: Author's calculations, Forsikring and Pension (2019), www.nav.no/no/nav-og-samfunn/ kontakt-nav/oversikt-over-satser/minste-pensjonsniva, www.pensionsmyndigheten.se/forsta-din -pension/sa-fungerar-pensionen/garantipension-om-du-har-lag-pension

Figure 10.2 The level and composition of minimum benefits for a single pensioner, 2019

The top panel confirms that the gross minimum pension is by far the highest 
in Norway, and that this is reinforced by minimum pensioners not paying any income tax. In Denmark the minimum pensioner pays a substantial amount in income tax, while the Swedish minimum pensioner only pays a very modest amount, primarily due to the general progressivity of the Swedish pension system and the low level of the minimum pension. The cross-national differences in the level of minimum protection are modified when housing allowances are taken into account. The housing allowance is most generous in Sweden and least generous in Norway.

The second panel shows that the ranking of the three countries is changed when we look at PPPs. The purchasing power of the minimum income offered to Danish single pensioners is slightly higher (1,922 US\$) than the corresponding figure in Norway (1,876 US\$) and significantly higher than in Sweden (1,465 US\$). The same ranking appears in the bottom panel, where the generosity of minimum protection is measured in relative terms, in per cent of the net average wage in the respective country. While the net minimum pension amounts to 58 per cent in Denmark, it is 51 per cent in Norway and 45 per cent in Sweden.

As already mentioned, the performance of Denmark would have been less favourable if the comparison had been made for married/cohabitating pensioners, and most likely the ranking of Norway and Denmark in the second and third panels would have been reversed or at least equalised.

These differences in the generosity of minimum protection align with observed differences in the prevalence of financial poverty among the elderly in Sweden compared to Norway and Denmark. In 2018, 7.8 and 8.9 per cent of the Norwegian and Danish elderly (65-plus) were classified as financially poor according to the EU indicator, while the same applies to 14.6 per cent of the Swedish elderly. ${ }^{3}$ While the poverty rates among the elderly have been falling very significantly in both Denmark and Norway over the last decade, they have remained stable at around 15 per cent in Sweden. This contrasts sharply with the situation in the 1980s, when Sweden featured one of the lowest financial poverty rates among the elderly in the Organisation for Economic Co-operation and Development (OECD) area (Kohl 1993; Smeeding 1993).

\section{INTEGRATION WITH EARNINGS-RELATED, CONTRIBUTORY PENSIONS}

In all the three countries, minimum protection offered to old-age pensioners is, to a varying degree, targeted towards pensioners with a low accrual of earnings-related pension rights. As already pointed out, Denmark is the only country providing an unconditional universal basic pension to all retirees, but also in Denmark a significant part of the total minimum protection is subject to general income and asset testing. In Sweden and Norway, the guarantee 
pensions are targeted by being tested only against benefits from the respective earnings-related NDC systems, ${ }^{4}$ and in these countries housing benefits offered to old-age pensioners are subject to broad income and assets testing.

Figure 10.3 illustrates how the various minimum benefits are related to the level of earnings-related pension benefits received. All values are expressed in relative terms using the average gross wage in each country as the anchor.

As illustrated in the Danish panel, the amount received from the basic pension is unrelated to the receipt of other pensioner income, and one could have chosen to let this be the first layer in the graph, before the contributory/ earnings-related benefit component. As already pointed out, contributory pensions in Denmark will have a smaller part stemming from the ATP system where only the number of years in employment count and a (much) larger part stemming from the system of earnings-related occupational pension schemes that reached a high coverage rate at the beginning of the 1990s. The remaining components of the Danish minimum protection system are all subject to general income and asset testing. The most important - at least for single pensioners - is the pension supplement, which operates with a rather high free amount and a relatively mild tapering of 30 per cent against incomes above the free amount. Consequently, the benefit is only tapered off completely when the level of contributory pensions reaches 75 per cent of the average wage. In addition, the tapering of the Danish housing allowance is relatively mild, which means that the benefit is only fully removed for single pensioners with contributory benefits equivalent to 56 per cent of the average wage.

The benefit structures in Norway and Sweden are simpler, with the guarantee pension being tapered off against earnings-related benefits from the public NDC/FDC schemes, and more broadly income-tested housing allowances. The latter component is much more important in Sweden compared to Norway. ${ }^{5}$ Primarily due to the fact that the guarantee pension is relatively generous in Norway, the benefit is not tapered off completely before the earnings-related benefit reaches 41 per cent of the average wage, while the same happens in Sweden when the level of earnings-related benefits reaches a level equivalent to 30 per cent of the average wage. The opposite is the case for the respective housing allowance benefits that are much more generous in Sweden, and partly as a consequence of this, the tapering takes place over a longer interval. The housing benefit is tapered off in Sweden when the private/earnings-related pension exceeds 45 per cent of the average wage, while the same happens in Norway when the private/earnings-related pension reaches 31 per cent of the average wage.

Overall, it is apparent that the minimum protection systems are more strongly targeted towards pensioners with low earnings-related benefits (and, hence, with low lifetime earnings) in Norway and Sweden compared to Denmark. For a given level of minimum protection offered, less strict targeting means that 


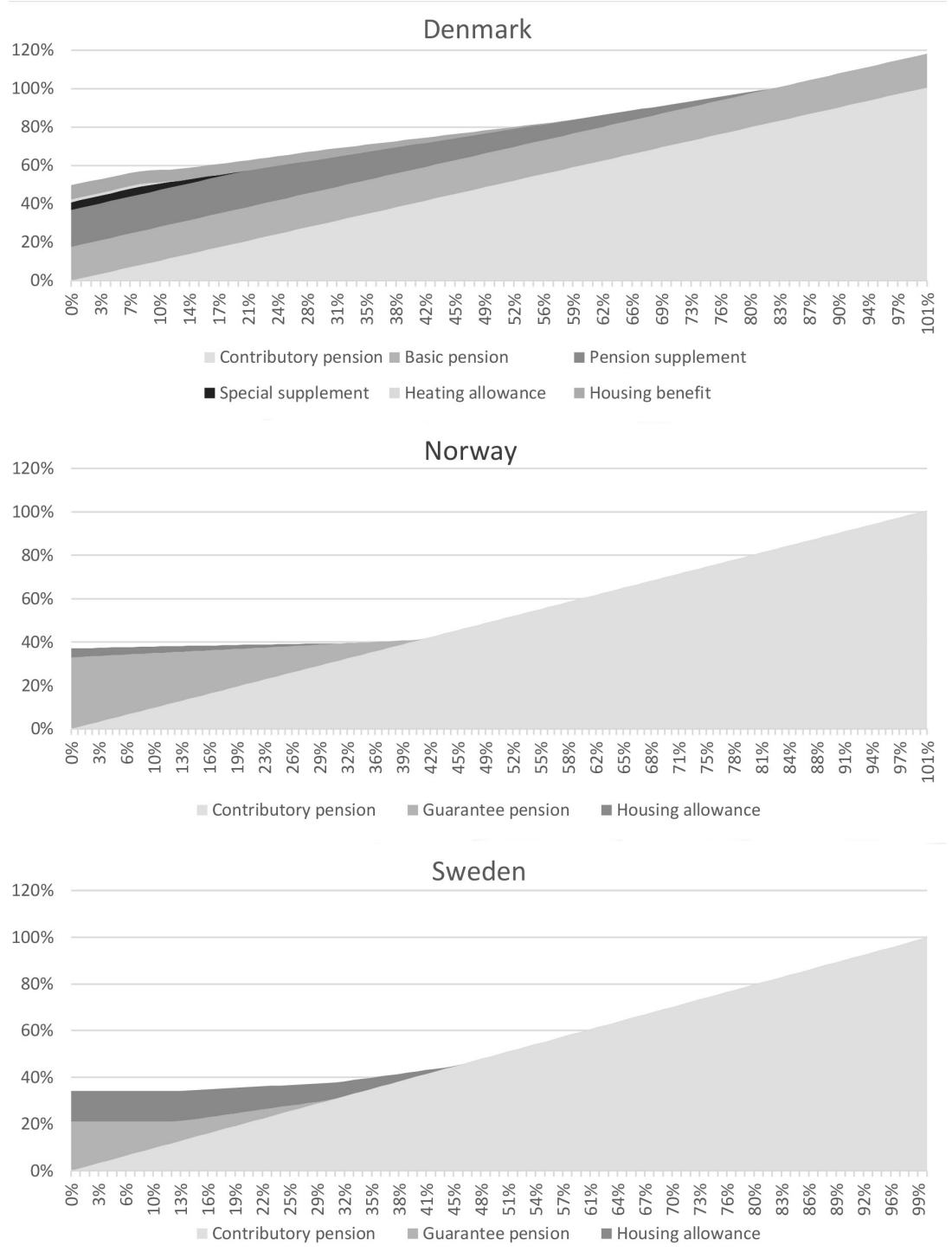

Source: Author's calculations - see endnote 2 about assumptions made related to housing costs and rents.

Figure 10.3 Pension benefits as a function of contributory pensions; per cent of average wage, 2019

the non-contributory benefits reach higher up in the income distribution among 
retirees and their redistributive effect is potentially stronger since it involves a larger share of the income distribution among old-age pensioners. The very strong targeting of the Swedish and Norwegian minimum protection systems mean that redistribution only affects the lower part of the income distribution among old-age pensioners, and for those who are affected the marginal gain in income from having built up contributory pension rights is seriously curtailed.

This is even more clearly brought out in Figure 10.4, which shows how the tapering/income testing of minimum pensions and the total package of minimum protection represents an implicit tax on contributory/earnings-related pension rights. The graph depicts how the total income of an individual is affected by an additional amount from contributory pensions. The tapering of minimum benefits implies that an additional amount received in contributory pensions is offset by reduced minimum benefits, and the effect is similar to a tax on contributory benefits. The rate of this implicit tax varies between 0 (no tapering) and 100 (when the additional contributory benefit is completely offset, leaving total income unchanged). The implicit tax rate can also exceed 100 per cent if the reduction in minimum benefits exceeds the increase in contributory pensions.

In Denmark the tapering of minimum benefits produces implicit marginal tax rates on contributory pensions which remain well below 50 per cent over the entire tapering interval. The only exception is the spike when contributory pensions constitute just above 10 per cent of the average wage, and the very high implicit tax in this short range is due to the joint tapering off of the two minor means-tested benefits, the special supplement and the heating allowance. But, of course, when ordinary income taxation is added to this, the compound marginal tax rate is significantly higher, and it has been shown to reach levels just above 70 per cent over a long range (Pensionskommissionen 2015, p. 17).

In Norway the implicit marginal tax rate associated with the tapering of the guarantee pension is 80 per cent. When adding the effect of means-testing of the housing allowance, we arrive at a total implicit marginal tax rate of 95 per cent over a broad interval. If the effect of income taxation had also been added to this, the marginal tax rate on contributory pensions comes very close to 100 per cent. In other words, contributory pension rights up to a level corresponding to 40 per cent of the average wage make very little difference to the recipients. Only when the guarantee pension is completely tapered off at a contributory pension corresponding to about 42 per cent of the average wage does the implicit marginal tax rate fall to zero, and the recipients actually start to benefit from additional earned pension rights.

In Sweden the implicit marginal tax rate associated with the guarantee pension is initially 100 per cent, but it is reduced to 48 per cent when the contributory benefit reaches about 14 per cent of the average wage, and it falls 


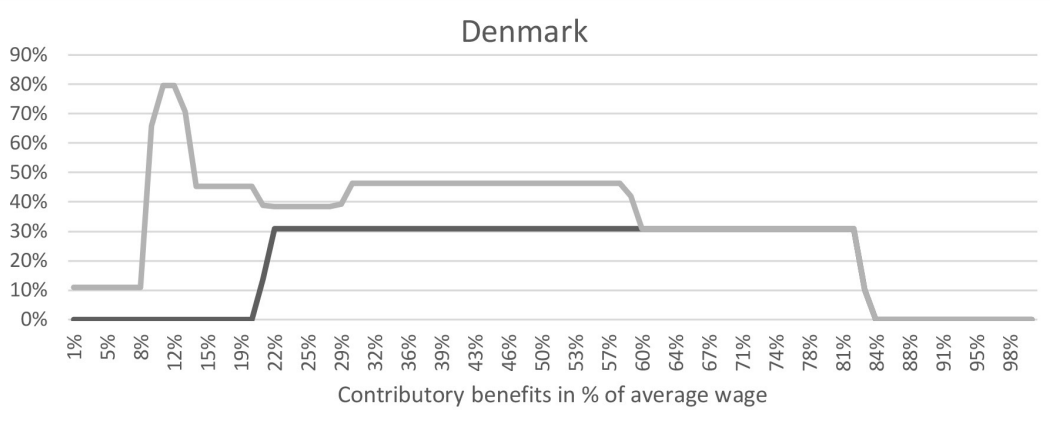

Minimum pensions $\quad$ Minimum benefits (including housing benefits)

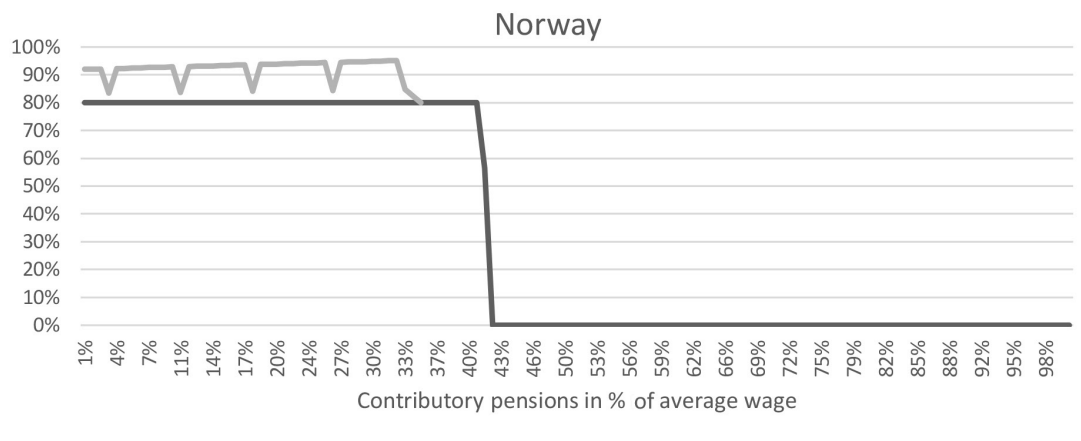

Minimum pension $\quad$ Minimum benefit (incl. housing benefits)

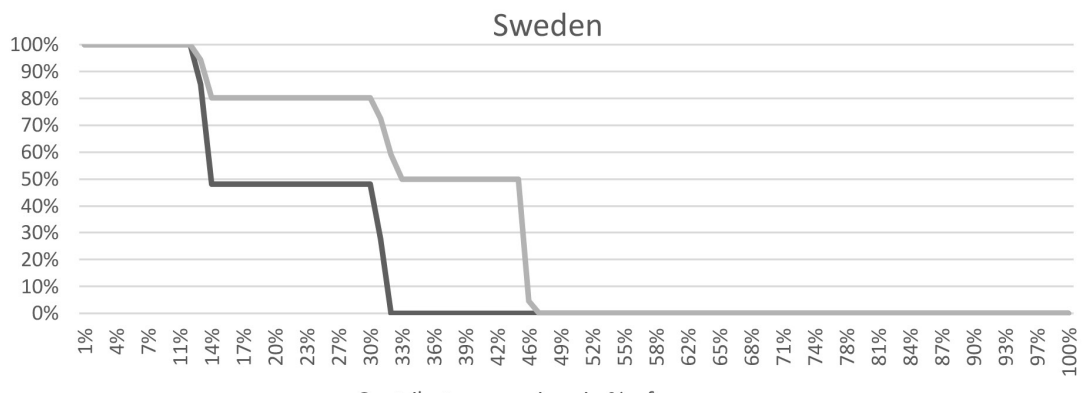

Contributory pensions in \% of average wage

Minimum pension $\quad$ Minimum benefit including housing benefits

Source: Author's calculations.

Figure 10.4 Implicit marginal tax rates on contributory pensions, 2019

to zero when the contributory benefit reaches 30 per cent of the average wage. 
The relatively short interval with very high marginal tax rates is primarily the result of the relatively low level of the Swedish guarantee pension. The Swedish housing allowance significantly improves the level of minimum protection offered to old-age pensioners (singles in particular), but it also significantly prolongs the interval with high marginal tax rates on contributory pensions.

\section{CONCLUDING REMARKS}

In Norway and Sweden minimum protection in old age has recently been reorganised in connection with major NDC pension reforms that are intended to improve the economic sustainability of the national pension systems, partly by limiting the growth of public pension expenditure and partly by stimulating higher labour force participation. The Danish system of minimum protection in old age that operates in the context of a mainly private, negotiated system of earnings-related pensions has been characterised more by continuity.

With respect to benefit generosity, the Danish and Norwegian systems of minimum protection are fairly similar, while the level of minimum protection offered to old-age pensioners in Sweden is significantly lower. This holds both in terms of absolute purchasing power and in terms of relative benefit levels measured against the average net wage. The difference is most pronounced when looking at the minimum pensions proper, but it holds up even when the relatively generous Swedish housing allowance is taken into account. Statistics provided by Eurostat (2021) confirm that financial poverty is much more prevalent among the aged (age 65 and beyond) in Sweden compared to the two other Scandinavian countries, where the financial poverty rates have declined significantly over the last decade.

The existing indexation rules in the respective countries indicate that these differences are likely to be perpetuated, and perhaps even amplified. The most generous indexation rules are found in Denmark, where full wage indexation was recently put in place. However, this must be seen in light of the fact that the age at which the minimum benefits can be taken out is about to be raised from the current 65 years to 67 . Furthermore, it has been decided that the pensionable age will later be raised further in line with increases in longevity of the Danish population. In Sweden the guarantee pension is only indexed with prices, while in Norway full wage indexation is modified by the application of longevity adjustments to the guarantee pension.

As we have seen, the targeting of minimum pensions and minimum benefits more generally gives rise to high implicit marginal tax rates on contributory/ earnings-related pensions in all three Scandinavian countries. In both Sweden and Denmark this has figured as a serious concern in current policy debates. 
In Sweden recent discussions about raising the level of minimum protection have resulted in only modest adjustments (Socialdepartementet 2018), and the main argument made against more resolute changes is that they would increase the taper interval and reduce the real gain associated with contributing to the NDC/FDC system for individuals with moderate lifetime earnings. In Norway stronger priority has been given to poverty prevention among the elderly, but with the cost of actually making participation in an earnings-related public pension system illusory for large segments of the workforce (see also Pedersen 2010).

Even if the implicit marginal tax rates are significantly lower in the Danish compared to the Norwegian and Swedish systems, the interaction between minimum protection and contributory pension rights has been pointed out as a serious problem in Denmark (Pensionskommissionen 2015), and a range of ad hoc measures have been taken recently to make sure that continued employment and payment of pension contributions for older workers actually pays off.

The fact that the Danish earnings-related schemes are private and have been built up as a result of trade unions giving up wage increases in exchange for pension contributions might help explain why high marginal tax rates on contributory pension benefits are politically less acceptable compared to Norway and Sweden, with a public, obligatory earnings-related system.

In all three countries, however, the same basic dilemma can be identified. On the one hand we have distributive concerns that require high minimum benefits. On the other we have concerns about improving or maintaining incentives for labour supply, and concerns about fairness in terms of maintaining a significant contribution/benefit link that requires implicit marginal tax rates on contributory pensions to be kept low for as many as possible. The Swedish and Norwegian system, combining an NDC pillar with a targeted minimum guarantee, does not in and by itself solve this dilemma, although it might help make it less politically controversial to uphold a minimum protection system that creates high implicit marginal tax rates on contributory pensions.

\section{NOTES}

1. Average net wages are obtained from the OECD Taxing Wages database: https:// stats.oecd.org/Index.aspx?DataSetCode=AWCOMP.

2. Housing benefits are calculated using the following somewhat arbitrary assumptions about housing expenditures (rents) in the respective country cases. In Norway it is assumed that the housing expenditure of the single pensioner is equal to the maximum supported expenditure for a person resident in a major city (not Oslo): NOK 83,100. For the Swedish case a rent of SEK 60,000 is assumed, which gives a housing allowance of SEK 5,149 per month, which is close to the absolute maximum. For Denmark it is assumed a rent of DKR 60,000 per year (excluding expenditure on heating that is compensated for through a special heating subsidy). 
3. The official label of this indicator is 'At-Risk-of-Poverty', and it classifies an individual as poor if the household income is less than 60 per cent of the population median. The figures are calculated by Eurostat based on data from European Union Statistics of Income and Living Conditions: https://ec.europa.eu/eurostat/ tgm/table.do?tab=table\&init $=1 \&$ language $=$ en $\&$ pcode $=$ tespn $050 \&$ plugin $=1$.

4. In Sweden estimated benefits from the FDC system (Premiepensionen) also enter the calculation of the guarantee benefit.

5. The transition to the NDC system where the guarantee pension takes care of minimum protection will only take full effect for individuals born in 1963 or later. Even so, I have chosen to show the benefit structure of the new system while using 2019 figures for the level of minimum protection.

\section{REFERENCES}

Baldwin, Peter (1990), The Politics of Social Solidarity: Class Bases of the European Welfare State 1875-1975, Cambridge: Cambridge University Press.

Christensen, Arne Magnus, Dennis Fredriksen, Ole Christian Lien and Nils Martin Stølen (2012), 'Pension Reform in Norway: Combining an NDC Approach and Distributional Goals', in Robert Holzmann, Edward Palmer and David Robalino (eds), Nonfinancial Defined Contribution Pension Schemes in a Changing Pension World, Volume 1: Progress, Lessons and Implementation, Washington, DC: World Bank, pp. 129-154.

Elmér, Åke (1986), Svensk socialpolitik, Stockholm: Liber.

Eurostat (2021), European Union statistics of income and living conditions, https://ec .europa.eu/eurostat $/ \operatorname{tgm} /$ table.do? tab=table \&init=1\&language=en\&pcode=tespn 050 \&plugin=1.

Forsikring og Pension (2019), Sociale ydelser - hvem, hvad og hvornår: håndbog i den sociale lovgivning med regler og ydelser 2019, Hellerup: Forsikring og Pension.

Hort, Sven E. O. (1990), Social Policy and Welfare State in Sweden, Lund: Arkiv Förlag.

Kangas, Olli, Urban Lundberg and Niels Ploug (2010), 'Three routes to pension reform: Politics and institutions in reforming pensions in Denmark, Finland and Sweden', Social Policy \& Administration 44 (3), 265-284.

Kohl, Jürgen (1993), 'Minimum Standards in Old Age Security and the Problem of Poverty in Old Age', in Anthony B. Atkinson and Martin Rein (eds), Age, Work and Social Security, New York, NY: St. Martin's Press, pp. 224-252.

Könberg, Bo, Edward Palmer and Annika Sundén (2000), 'The NDC Reform in Sweden: The 1994 Legislation to the Present', in Robert Holzmann and Edward Palmer (eds), Pension Reform: Issues and Prospects for Non-Financial Defined Contribution (NDC) Schemes, Washington, DC: World Bank, pp. 449-466.

Molin, Björn (1965), Tjänstepensionsfrågan. En studie i svensk partipolitik, Göteborg: Akademiförlaget.

NOSOSCO (1998 to 2016/2017), Social Protection in the Nordic Countries. All available publications. København: NOSOSCO.

OECD (2019), Pensions at a Glance 2019, Paris: OECD.

Pedersen, Axel West (1990), 'Fagbevegelsen og folketrygden. LOs målsetninger, strategi og innflytelse i pensjonspolitikken 1945-1966', Fafo-report no. 110, Oslo: Fafo. 
Pedersen, Axel West (2010), 'Pensjonsreformen - status og konsekvenser for insentivene til arbeid', ISF-report no. 2010/1, Oslo: Institute for Social Research.

Pedersen, Axel West (2018), 'Assessment of Pension Adequacy in Norway 2017', ESPN Thematic Report, Brussels: European Commission.

Pedersen, Axel West, Jon Hippe, Anne Skevik Grødem and Ole Beier Sørensen (2018), 'Trade unions and the politics of occupational pensions in Denmark and Norway', Transfer 24 (1), 109-122.

Pedersen, Axel West, and Stein Kuhnle (2017), 'The Nordic Welfare State Model', in Oddbjørn Knutsen (ed.), The Nordic Models in Political Science: Challenged, But Still Viable? Oslo: Fagbokforlaget, pp. 219-238.

Pensionskommissionen (2015), 'Det danske pensionssystem - internationalt anerkendt, men ikke problemfrit', København: Pensionskommissionen.

Petersen, Jørn Henrik, and Klaus Petersen (2009), 'The Coalition of the Willing and the Breakthrough of the Welfare State: The Political History of the Danish People's Pension', in Jørn Henrik Petersen and Klaus Petersen (eds), The Politics of Age: Basic Pension Systems in a Comparative and Historical Perspective, Frankfurt: Peter Lang, pp. 19-40.

Pettersen, Per Arnt (1982), Linjer i norsk sosialpolitik, Oslo: Universitetsforlaget.

Pettersen, Per Arnt (1987), Pensjoner, penger, politick, Oslo: Universitetsforlaget.

Salminen, Kari (1993), Pension Schemes in the Making: A Comparative Study of the Scandinavian Countries, Helsinki: Central Pension Security Institute.

Scherman, Karl Gustav (2001), Den nya pensionen. En reform med stora problem, Stockholm: Sveriges Pensionärsförbund.

Smeeding, Timothy (1993), 'Cross-National Patterns of Retirement and Poverty among Men and Women in the Mid 1980s: Full Stop or Gradual Withdrawal?', in Anthony B. Atkinson and Martin Rein (eds), Age, Work and Social Security, New York: St. Martin's Press, pp. 91-114.

Socialdepartementet (2018), Ds 2018: 8 'Översyn av grundskyddet för pensionärer. Inriktning för ett nytt grundskydd', Stockholm: Regjeringskansliet.

SOU (1994), 'Reformerat pensionssystem', SOU 1994:20, Stockholm: Regjeringskansliet.

Vesterø Jensen, Carsten (1985), Det tvedelte pensionssystem, København: Forlaget Samfundsøkonomi og planlægning. 